\title{
YOUTH LABOUR MARKET IN ROMANIA'S DEVELOPMENT REGIONS IN THE FRAMEWORK OF SUSTAINABLE DEVELOPMENT AND OF A KNOWLEDGE-BASED ECONOMY
}

\author{
Mariana Bălan \\ Institute for Economic Forecasting - NIER, Romanian Academy \\ e-mail: dr.mariana.balan@gmail.com
}

(Received, September 2017; Accepted November 2017)

\begin{abstract}
Even if the issue of youths' inclusion in the labour market was always an important item on political agendas, during the last two decades this issue had particular relevance. In the last years, unemployment for this age group had unprecedented amplitude, reaching $20.6 \%$ in Romania in 2016. Modern societies provide for youths opportunities, still they are faced with major challenges related to the education and training and access to the labour force market.

During the last decades, the world economy shifted in a continuous process from development based on traditional factors to the knowledge-based economy. The development of the knowledge-based economy leads to changes in labour force demand also: new skills and competences are required. As new technologies are implemented, the demand for high-skilled workers increases, especially for high-skilled ones in the field of Information and Communication (IC), and the demand for low-skilled workers decreases. The paper presents a brief characterisation of the labour force market at the level of Romania's regions of development and an analysis of the particularities of the youths' labour market in the context of sustainable development and of the new economy as well as some advantages of using young labour force for sustainable development.
\end{abstract}

Key words: youth, labour market, region, development, unemployment rate, employment rate

J.E.L. CODES: D80, J44, J62, J82, O11, R11, R23

\section{Introduction}

The youth labour market is one of the most often encountered topics on the working agenda of all economic and social supra-structures: the International Labour Office (ILO), Organisation for Economic Co-operation and Development (OECD), G-20 all of them underpinning that the current situation of youths is one of the most difficult at world level. A comparative analysis between the flagship initiatives of the EU-28 included in the "Europe 2020" strategy and the objectives aimed by other international bodies regarding policies dedicated to youths (OECD and ILO, 2014) highlight the imperative of intensifying the actions pursuing their better integration on the labour market, but also better performances regarding youths' employment. 
Bălan M. (2017)

Youth Labour Market in Romania's Development Regions in the Framework of Sustainable Development and of a Knowledge-based Economy

The specialised literature discusses more and more often about the present generations of youths under the generic name of the " $Y$ " or " $Z$ " generations who on medium- and long-term will become one of the dominant components of labour market. These generations are characterised firstly by the political, social and economic conditions in which they were born, and spent their first years of school, underwent various educational levels including here vocational training in an extremely fluid environment of political, economic, social and technological changes of high intensity. They are the generations born, nurtured and educated in a period of overall economic growth supported at global level by political changes in a Europe in full process of eastern expansion, when social actions improved and intensified in order to eliminate discrimination but, above all, they are the generations who know and valorise fully the opportunities provided by the new information and communication technologies. Personal computers, internet, but also applications used by industries, in education and culture and in most fields of daily life contributed next to the above mentioned components to cultural and mentality changes of these generations. From this viewpoint, some of the shifts that changed to a certain extent the characteristics of these generations are: i) an increased level of expectations and demands regarding employers, but also incomes and the quality of the workplace (Parment, 2009); ii) higher levels of flexibility and higher availability of changing the environment, or the working conditions; iii) higher wish of exploring new possibilities and opportunities, frequently translated into the fact that these generations no longer consider as necessary or desirable to have the same employer or to work in the same branch their entire active life (Enderle, 2008).

Nevertheless, conflict appears between these characteristics signalling a mentality and culture change regarding work in the case of the young generation, and the realities of the labour market on which they prepare to enter, just like between the dissonance between this future horizon of the youths and the access to the necessary resources for transforming this horizon into reality.

The development of the knowledge-based economy leads also to changes in the demands of the labour market: new competences and skills are required. In industrialised countries, under the conditions in which knowledge-based industries expand swiftly, the demands on the labour market changed accordingly. Thus, together with the implementation on the new technologies the demand for highskilled workers increased, in particular for those with high-skills in the field of IC and the demand for low-skilled workers decreased.

International statistics show that innovative companies and with excellent financial results have a large number of youths as employees. At the same time, the youths 
Bălan M. (2017)

Youth Labour Market in Romania's Development Regions in the Framework of Sustainable Development and of a Knowledge-based Economy

have knowledge about the new media and virtual workplace instruments, and these instruments are indispensable to the future labour market.

To analyze the particularities of the youth labor market, both at national and regional level, were used specific techniques of descriptive statistics.

\section{Particularities and issues of the youths' labour market}

The youths' labour market is defined by its specifics, respectively the fact that it addresses a relatively narrow population segment, the population with ages between 15 and 24 years of age, and between 25 and 29 years of age. The population ageing phenomenon with which all European countries are faced puts its fingerprint on this population segment, as there are smaller cohorts of youths assimilated into the active population, including in the labour force. The demographic situation of each country is reflected in the education and vocational training system, but also in the economic growth, social and human development perspectives on long-term.

When considering the realities of the labour market on which the youths intend to enter after graduating a certain educational or skilling level, a series of the 'weaknesses' of the $\mathrm{Y}$ and $\mathrm{Z}$ generations come to the fore:

- the reluctance shown by employers in hiring the young labour force;

- the difficult situations in which youths find themselves often determine them to accept contracts on determined periods, or part-time contracts, and these are the instances pushing them to survival solutions for them and their families in the 'grey' areas and thus potential candidates to social exclusion;

- difficult transition because the training provided by the educational or vocational system is behind as compared with the competences and skills demanded on the market.

In this context, a first delineation of the youths' labour market between the two poles might be done:

- well-trained youths who are trained for activities in high-skilled fields;

- young individuals who did not succeed in taking advantage of the opportunities provided by the education system, or by the vocational training system and who are at the opposite pole with low skills or even inexistent ones.

A second delineation is given by the characteristics of the generation and of each individual regarding the approach to the labour market - expectations faced with the immediate reality of identifying a job. High expectations of youths are often faced in particular with the expectations of the employers according to the labour demand determined by the short and medium-term economic development, but also by the long-term perspective. Here, the intention of the youths to achieve material 
Bălan M. (2017)

Youth Labour Market in Romania's Development Regions in the Framework of Sustainable Development and of a Knowledge-based Economy

and social status expressed firstly by developing their career and expertise is completely different from the one of employers: young and experienced.

The third delineation is determined by the development level on countries/regions because labour markets are influenced directly by these. From this viewpoint, it is found that, the most affected were the advanced markets and economies where the turnaround of the labour market for youths is much too slow, with 'scaring' effects much higher than in the case of emerging markets and of developing markets.

A last delineation between the youths depends on the type of unemployment they are included in voluntary or involuntary unemployment. Young individuals in voluntary unemployment are belonging, most likely, to the categories of the " $Z$ " and "Y" generations who have a high threshold for personal expectations and who decide whether the available job is attractive enough from the viewpoint of the 'know-how' of competences and specific high-skills.

Those in involuntary unemployment are young individuals faced directly with the consequences of the mismatches that can become even more intensified between labour demand and supply as it is expressed on one hand in the requirements of the employers in the labour market and, on the other hand, by the results (expressed in graduates) provided by the educational systems at national level.

Between these two categories of young either voluntary or involuntary unemployed a specific niche emerged represented by the NEET youths (not in employment, education or training) it is a specific, heterogeneous category cumulating characteristics of both groups and covering the entire range: i) from skills and competences which would allow them to find employment in the labour market, to minimal or inexistent skills and competences; ii) from lacking interest in searching for a job because the market is not attractive and rewarding enough up to the discouragement after several failed attempts in identifying a stable job. This niche is the one that generates most debates and concerns precisely because of its heterogeneous character, and of the multitude of circumstances and conditions that led to its formation.

The increase in the NEET share during the crisis was dramatic and signalled the changes that the labour market for youths will undergo in the future.

Thus, if the labour market for youths is analysed from the viewpoint of the main characteristics it is found that on a segmented labour market they are included in a niche which is subjected to even higher segmentation and to inherent rigidities.

In the context of increased job polarisation but also due to higher economic uncertainty as result of the successive financial crises, young individuals find themselves in a position that makes them extremely sensitive to economic fluctuations (Verick, 2011; Neagu, 2016; Berlingher, 2014).

40 DE GRUYTER OPEN
Studia Universitatis "Vasile Goldis" Arad. Economics Series Vol 27 Issue 4/2017 ISSN: 1584-2339; (online) ISSN: 2285 - 3065

Web: publicatii.uvvg.ro/index.php/studiaeconomia.Pages $36-54$ 
Bălan M. (2017)

Youth Labour Market in Romania's Development Regions in the Framework of Sustainable Development and of a Knowledge-based Economy

Vulnerabilities of structural nature are the outcome of the conditions in the personal and social environment, the status of the youth is affected first by the family status. If the young individual comes from a poor family (autochthonous or immigrant) with low education level, then the 'model' tends to keep with the family development, meaning early school-leaving and fit only for jobs in the lower part of the occupational grid, both from the viewpoint of skills and from the one of achieved wages or incomes. This leaves behind the 'scaring' effects but also contributes to longer periods of unemployment and trajectories lacking perspective. Nevertheless, the youths have also many of the characteristics that make the most dynamic segment like high mobility as they are more flexible and mobile, with higher absorption and learning capacity of the new required competences demanded by the new digital society.

\section{Employment and unemployment of youths on the labour market in Romania's regions of development}

While unemployment is the most pressing challenge for youths, the employment rates decreased during the last years. Thus, in 2016 at national level the employment rate of the youths with ages between 15 and 24 years of age was of $22.3 \%$, on decrease by 2.2 pp against 2015 and much under the employment rates for the population segments with ages between 25-54 years and 55-64 years (Figure 1).

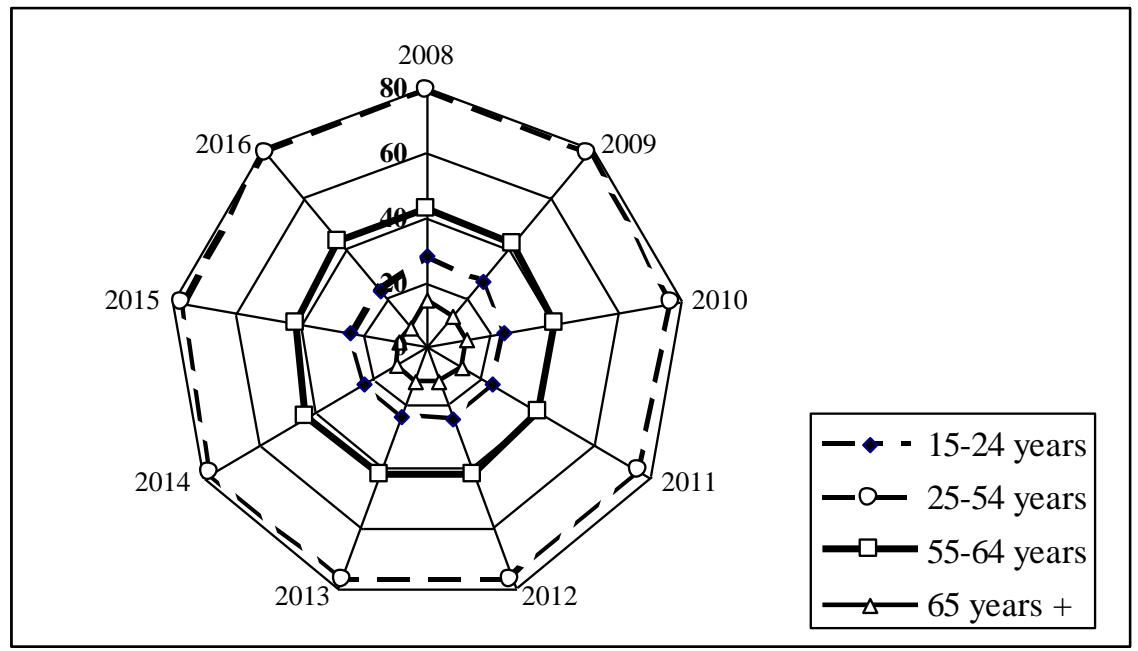

Figure 1 Evolution of employment rates on age groups (\%)

Data source: TEMPO-online databank, National Institute of Statistics, www.insse.ro

DE GRUYTER OPEN
Studia Universitatis "Vasile Goldis" Arad. Economics Series Vol 27 Issue 4/2017 ISSN: 1584-2339; (online) ISSN: 2285 - 3065

Web: publicatii.uvvg.ro/index.php/studiaeconomia.Pages $36-54$ 
Regarding youths' employment also for 2016, between regions there are significant differences in their employment. The youths are much more involved in the labour market in the North-East region (33.3\%) - the region with the highest weight of young population (12.7\%) and Bucharest-Ilfov (23.9\%) and both regions have values above the national average of $22.3 \%$. In turn, the employment rates of the youths are below the national average in all other six regions, the lowest value being registered in the West region (16\%).

In 2016, the employment rate of the youths with ages between 15 and 24 years at Romania's level was on decrease by 5.9 pp against the year 2008 and by 2.2. pp against the year 2015. Percentage changes in the employment rate of youths in the period 2008-2016 in Romania's regions of development are presented in Figure 2.

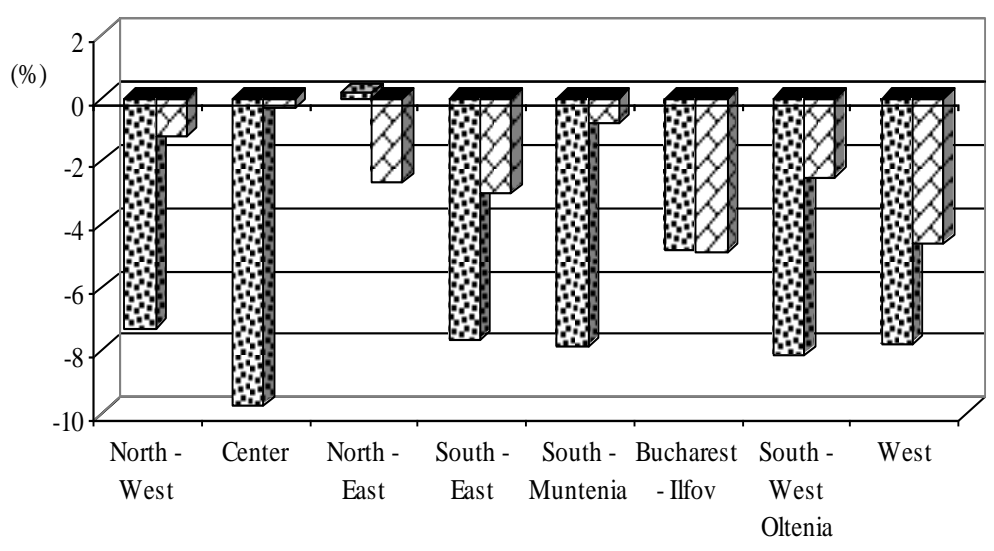

Figure 2 Percentage changes in the employment rate of youths in the period 2008-2016 in Romania's regions of development

Data source: TEMPO-online databank, National Institute of Statistics, www.insse.ro

In all regions of development, the employment rate of the youths with ages between 15 and 24 years of age was higher for men (Figure 3 ) and higher in the rural area than in the urban area (Figure 3).

The decline in the employment of the young individuals was shown both for loweducated and skilled individuals, and for those with higher education. The analysis of the structure of the young population in territorial profile according to the education level highlights the fact that the highest weight is represented by low trained young individuals (Figure 4). 
Youth Labour Market in Romania's Development Regions in the Framework of Sustainable Development and of a Knowledge-based Economy

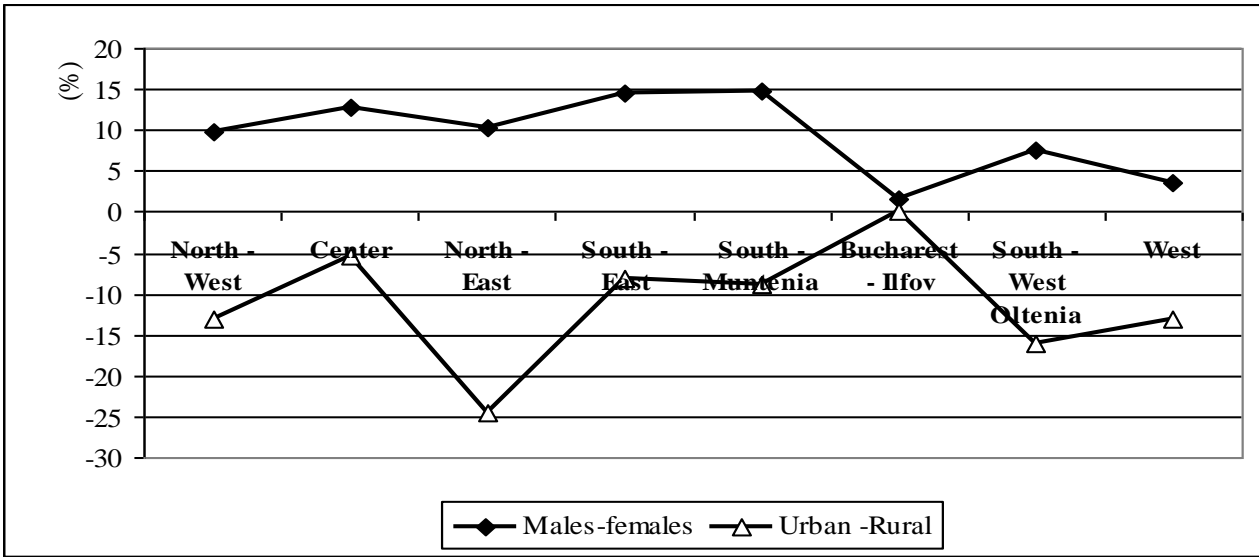

Figure 3 The gap between the employment rate for men and women and on areas of residence for the age group 15 to 24 years of age, in the year 2016, (\%)

Data source: TEMPO-online databank, National Institute of Statistics, www.insse.ro

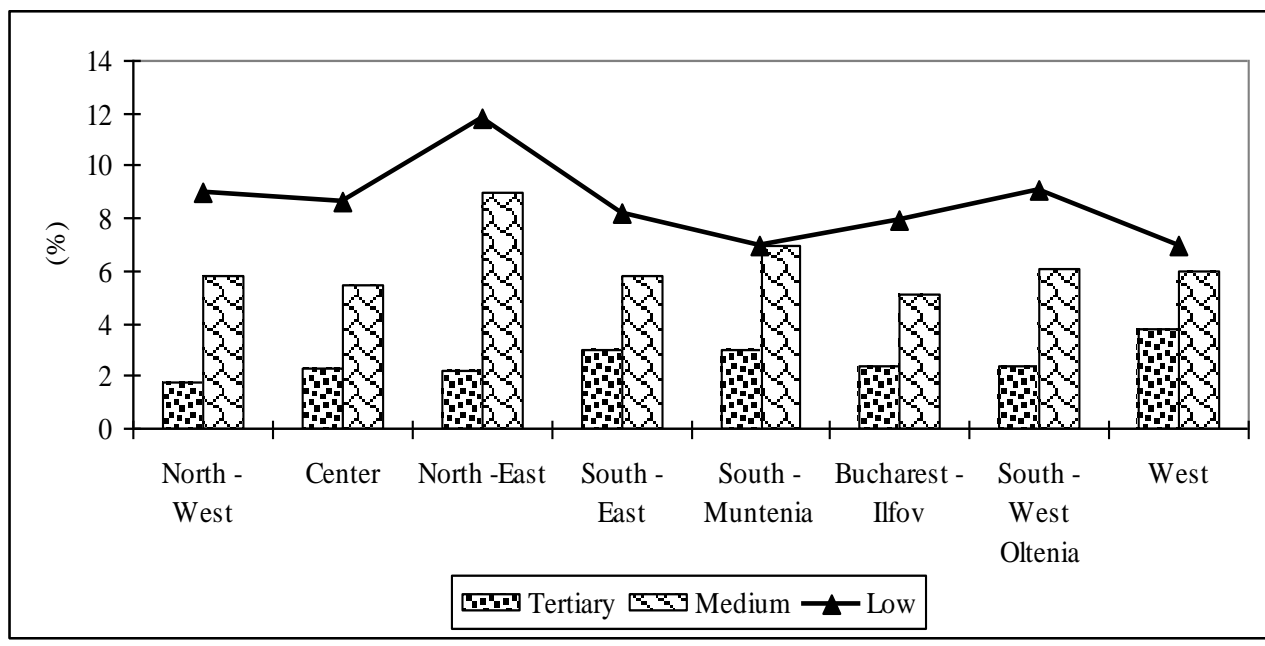

Figure 4 Employment structure, at territorial level, by educational level, for the age group 15-24 years, in 2015

Data source: Romania's Yearbook 2016, National Institute of Statistics

The unemployment rate for the age segment below 25 years of age, at Romania's level, was of $20.6 \%$ in 2016, on increase by 3.0 pp against the year 2008. If adults recorded an unemployment rate by $5.9 \%$ in the year 2016, the youths were faced

DE GRUYTER OPEN
Studia Universitatis “Vasile Goldis" Arad. Economics Series Vol 27 Issue 4/2017 ISSN: 1584-2339; (online) ISSN: 2285 - 3065 
Bălan M. (2017)

Youth Labour Market in Romania's Development Regions in the Framework of Sustainable Development and of a Knowledge-based Economy

with an unemployment rate by $20.6 \%$ (Figure 5 ). This means that the ratio between the youths' unemployment rate and the one of adults is of 3.49 at national level. The ratio was almost 4 or even higher in the regions Centre (4.56) and BucharestIlfov (4.21). The lowest value of this ratio was recorded in the region South-West Oltenia (2.78).

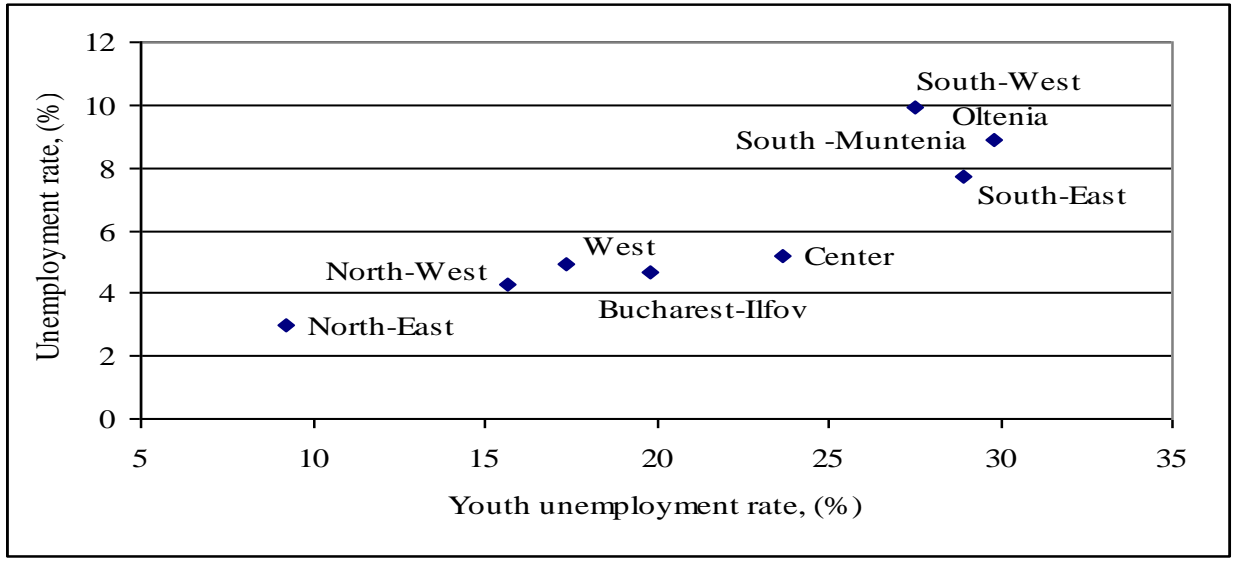

Figure 5 Unemployment rate in Romania's regions of development in 2016, (\%) Data source: TEMPO-online databank, National Institute of Statistics, www.insse.ro

On age groups, the unemployment rate among young women was higher than for men for this age group in the regions South-Muntenia (by $11.1 \mathrm{pp}$ ), South-East (by $11 \mathrm{pp}$ ), Centre (by $9.5 \mathrm{pp}$ ), North-East (by $1.2 \mathrm{pp}$ ) and North - East (by $0.4 \mathrm{pp}$ ), and lower in the regions West (by $10.2 \mathrm{pp}$ ), Bucharest- Ilfov (by $7.9 \mathrm{pp}$ ) and SouthWest Oltenia (by $5.3 \mathrm{pp}$ ).

Unemployment among youths depends also on their educational level. For the age group 15 to 24 years of age, in general, high unemployment is recorded among youths with pre-school, primary and lower-secondary education (levels 0-2).

According to the statistics of the National Labour Force Employment Agency (NLFEA), by the end of the year 2016, were registered 54410 youths with ages under 25 years of age (from among whom 21971 were women). From these, 2377 individuals had higher education, 22464 with upper-secondary and post-highschool education, and 29569 with primary, lower secondary and vocational education. The long-term unemployment rate was of $3 \%$, and the incidence of long-term unemployment (weight of persons in unemployment for one year and over in total unemployed) was of 50\%, respectively of about 265.000 individuals. 
Bălan M. (2017)

Youth Labour Market in Romania's Development Regions in the Framework of Sustainable Development and of a Knowledge-based Economy

Regarding the youths' unemployment rate on areas of residence, in 2016, only the regions North-West and Bucharest-Ilfov had higher values in the rural area than in the urban area. In all other regions, the youths' unemployment rate was higher in the urban area than in the rural area (Figure 6).

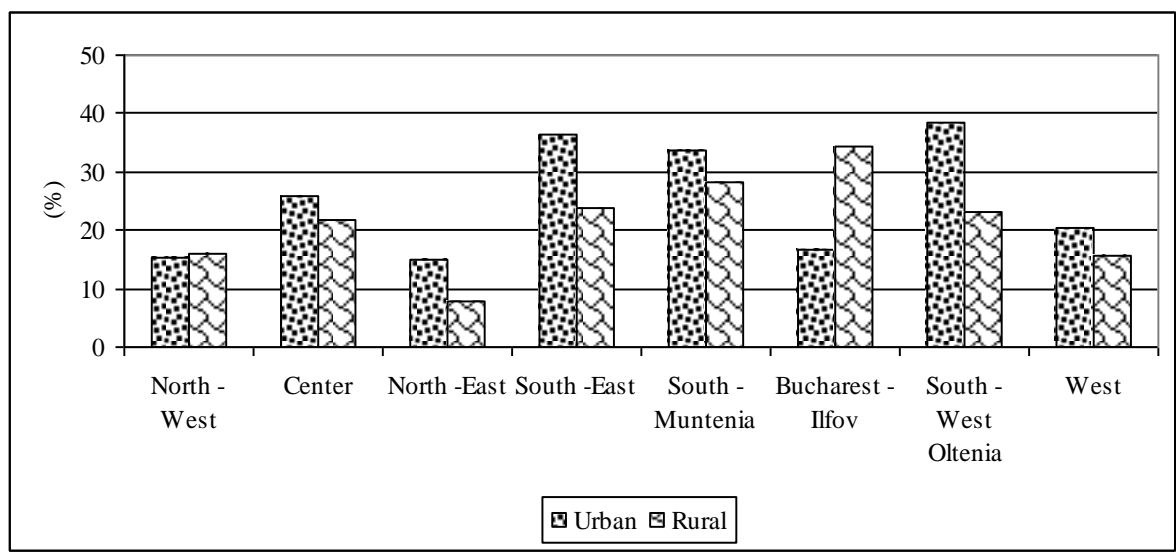

Figure 6 Youth unemployment rate (age group 15-24 years) on areas of residence, in 2016

Data source: TEMPO-online databank, National Institute of Statistics, www.insse.ro

In the current conjecture, the integration of youths in society can no longer pursue the traditional and linear model (as a succession of steps from school to work) and, as result, this model is replaced by diversified and individualised trajectories from school to work. Therefore, the mainstream approaches regarding the analysis of the vulnerable position of youths in the labour market are no longer efficient, many of these transitions failing to be highlighted by the conventional indicators of the labour force market.

Nowadays, one of the important challenges for each country is represented by the high values of the NEET rate. This is not only due to the risk of 'scarring effects', but also due to the negative effects of this statues on the future outcomes of the labour force market, both for the individual and for the community and society to which these young individuals belong (Gregg, 2001; Doiron \& Görgens, 2008; Schmillen \& Umkehrer, 2013; Möller şi Umkehrer, 2014; Gregg \& Tominey, 2005; Mroz \& Savage, 2006).

The analysis of the NEET rate development for young individuals in the age group 15 to 24 years of age in Romania highlights the fact that in the period 2008-2011 this rate increased from $11.6 \%$ to $17.5 \%$ and had thereafter an oscillating evolution, and reached $17.4 \mathrm{pp}$ in 2016. 
Bălan M. (2017)

Youth Labour Market in Romania's Development Regions in the Framework of Sustainable Development and of a Knowledge-based Economy

Regarding the situation at regional level for Romania are available data only regarding the age group 15 to 24 years of age (Eurostat statistics). The maximum difference registered in 2016 was considerable, by 14.8 percentages between a maximum recorded in the South-East region $(25.2 \%)$ and the minimum of only $10.4 \%$ recorded in the West region, a value under the national average of $17.4 \%$ (Figure 7). Other regions of Romania with low values of the NEET youth rate and under the national average are: the North-West region (11.3\%), Bucharest-Ilfov $(11.7 \%)$ and the North-West region with a rate of $13.9 \%$

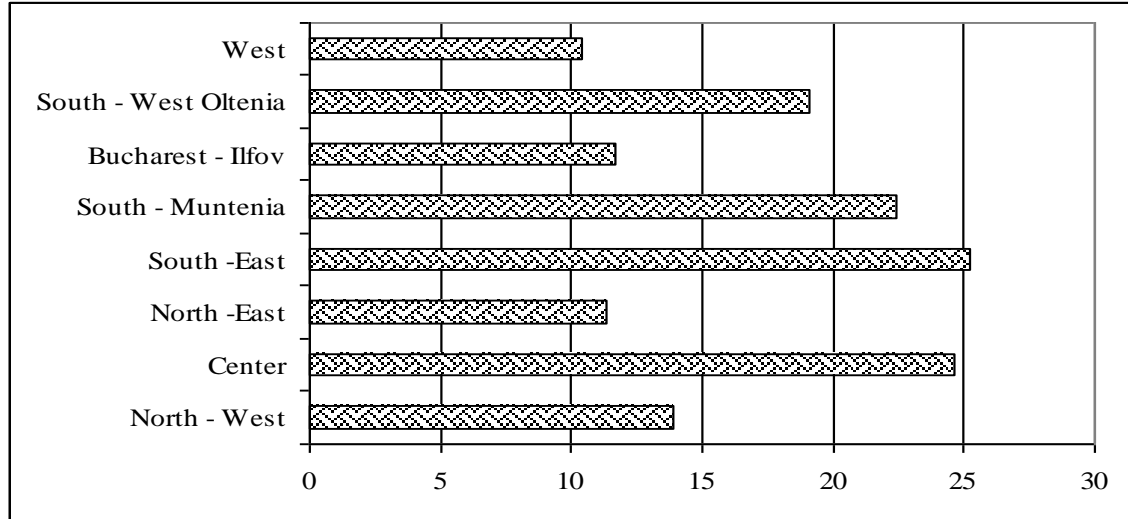

Figure 7 NEET youth rate in Romania's regions of development in the year 2016, (\%) Data source: Eurostat statistics, (online data code: [edat_lfse_22])

The NEET rate among youths was higher among men at national and regional level (Figure 8).

Entering into this category at young ages might have long-term consequences. The "scars" of this statue may have negative effects on future employment outcomes and on wage earnings, as well as negative consequences on the physical and mental health. At the same time, they might lead to drug consumption, involvement in criminal activities, and disengagement from life and society. As result of this status for a longer period of time, high variations of the social conditions might emerge: isolation, employment in uncertain working conditions and for low wages, criminality and physical and mental health issues, failure to set up a family or divorce, etc. 
Youth Labour Market in Romania's Development Regions in the Framework of Sustainable Development and of a Knowledge-based Economy

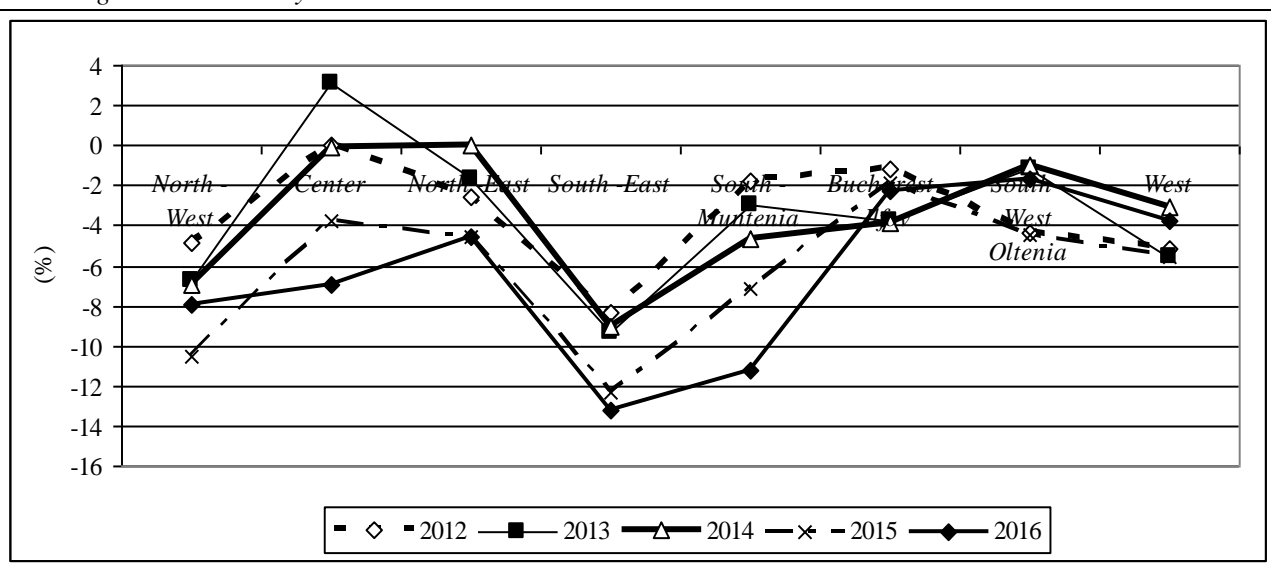

Figure 8 Evolution of the difference between the NEET rate of young women and men in the regions of development, $(\%)$

Data source: Eurostat statistics (online data code: [edat_lfse_22])

\section{Milestones of youths' labour market evolution in the knowledge-based society}

The knowledge-based society represents a new stage of human civilization, a new way of life which is superior qualitatively and involves the intensive use of information in all spheres of human activity and existence with major impact from the economic and social point of view.

During the last decades, a continuing process of the World economy took place of shifting from development based on traditional factors to the knowledge-based development. In this context, intangible goods (for instance education, technological knowledge, innovation, information management) become main factors of economic growth, contributing to intensifying the productivity of traditional production factors as the quantitative contribution of the latter becomes secondary.

Preparing workers to compete in the knowledge-based economy requires a new model of education and vocational training, a model of lifelong learning. The change speed in the knowledge-based economy has as effect also the swifter depreciation of aptitudes. In order to meet efficiently these changes, workers must be able to update competences permanently. In this context, companies no longer can rely exclusively on new graduates or new-comers on the labour market as main source of new skills and knowledge. It is necessary for schools and other educational institutions to train the workers for continuing learning. Lifelong learning is essential for allowing employees to compete in the world economy. 
Bălan M. (2017)

Youth Labour Market in Romania's Development Regions in the Framework of Sustainable Development and of a Knowledge-based Economy

The investments in human capital are essential for economic growth. At the same time, between the quality of education and consequently of the labour force and economic growth there is a strong correlation (Barro 2001, Hanushek şi Kimko 2000).

The end of the $20^{\text {th }}$ century and the beginning of the $21^{\text {st }}$ highlighted the need of adopting some new measures/reforms regarding the training of youths for the labour market in a knowledge-based economy.

In their work from the year 2008: „Skills for success in the knowledge economy" Cochran and Lekies synthesized from the specialized literature the required competences for youths in order to have success on the labour force market in the $21^{\text {st }}$ century, respectively:

- reasoning: critical thinking, problem-solving, creativity and innovation;

- communication: ability of communicating efficiently by using various methods and available instruments in today's environment;

- teamwork and leadership: interpersonal skills for working efficiently in a team and leading by collaboration, motivation and putting to good use the strengths of the co-workers;

- continuing learning and self-direction: continuing improvement of competences by assuming responsibilities in setting up objectives and improving skills and abilities for presenting initiatives;

- adoption of technologies and applications: a strong technological skills basis, including concepts and operations, selecting adequate instruments and solving issues based on the adequate technology;

- professionalism and ethics: to prove personal responsibility and efficient working habits (punctuality, productive and timely teamwork), as well as efficient management of the working time.

The weak insertion of youths in the labour force market, both at the level of the regions of development from Romania and at national and European level is determined by a lot of factors, from among which we mention:

- the lack of information, of access to social networks and poor connections between youths;

- lacking relevant competences for the job;

- lack of jobs requiring competences for the entry level;

- lacking experience and recommendations to increase the confidence of companies in the young individuals showing employment potential.

For companies, the youths represent an advantage because they meet both the quality of consumers and the one of innovators, as they are a category influencing the public opinion and dispose of technological know-how. As employees, the youths provide to the business environment direct information regarding 
Bălan M. (2017)

Youth Labour Market in Romania's Development Regions in the Framework of Sustainable Development and of a Knowledge-based Economy

preferences and tastes of their generation by promoting at the same time the goods and services of the employers.

In a knowledge-based economy, the ability to permanently innovate is the key to success in business. International statistics show that in the top of most innovative companies at global level are Apple, Facebook and Google, companies with outstanding financial results. All these companies have a very high number of young employees, the average age of the employees being 33 years of age for Apple, 26 years of age for Facebook and at Google employees' age is in average of 31 years.

At the same time, young individuals have know-how about the new media instruments and virtual workplaces, all of these being indispensable instruments for the future labour market. The online video technology, blogs, podcasts and software allowing for interaction are instruments supporting productivity when used efficiently.

In 2020, today's pupils and students shall be at the beginning of their career facing at least 30 years of professional life and some of them will have professions that don't exist today and other professions threatened by disappearance.

The transition to a knowledge-based economy presupposes also the transition to a green economy which affects the necessary of competences in various jobs and different sectors. Practically, the labour force market requires a balance between the development of generic competences regarding environmental protection (for instance waste diminishment, improving energy efficiency) and specific competences. Just as information and communication technology competences are currently essential for all individuals, the 'green' competences will be important for almost each job of the future.

At the same time, education and initial vocational training (EIVT) and continuing vocational training (CVT) share a double objective, respectively on one hand to contribute to increase the professional insertion degree and economic growth and on the other hand to meet the extended challenges at the level of the society and in particular promoting social cohesion. Attaining this double objective should provide to the young individuals and to adults as well attractive and challenging career opportunities and should be equally attractive to men and women, to all individuals with a high potential and who, irrespective of the reasons are faced with the risk of exclusion from the labour market.

In a knowledge society, a particular emphasis should be laid both in EIVT and CVT on promoting innovation, creativity and entrepreneurial spirit, as well as using IC.

Studia Universitatis "Vasile Goldis" Arad. Economics Series Vol 27 Issue 4/2017 ISSN: 1584-2339; (online) ISSN: $2285-3065$

Web: publicatii.uvvg.ro/index.php/studiaeconomia.Pages $36-54$ 
Bălan M. (2017)

Youth Labour Market in Romania's Development Regions in the Framework of Sustainable Development and of a Knowledge-based Economy

The insertion of youths on the labour market in a knowledge-based economy might be efficiently achieved if a series of measures are adopted at regional and national level, from among which we mention:

- identifying optimum solutions for the issue of youths on labour market. To this end, each generation has the responsibility of guiding the training of the future generation with the purpose of harmonious economic development. These objectives might be attained by concluding partnerships with governments, educational institutions, the civil society and even with the youths searching for jobs;

- investing in improving information resources for youths;

- realising investments intended to increase the access of youths to training programmes for developing job specific skills. An important role in this regard pertains to educational and vocational training institutions, but also to employers (who have the role of counselling and influencing for achieving better educational training that meets the real needs and challenges of the contemporary labour market);

- creation of and involvement in training programmes that stimulate experience gaining;

- commitment to youths: supporting training programmes, providing jobs and mentoring. Training on the job and mentoring might be an important element in the framework of an efficient mitigation strategy to the talent deficit and an innovative way of discovering, developing and managing the talent resources that companies need for being in agreement with their own business goals;

- realising investments aimed to diminish the entry-level job deficit;

- realising investments in educational programs of entrepreneurship in the academic environment and in vocational training centers. Promoting entrepreneurship is an indispensable component for ensuring sustainable economic growth. Promoting entrepreneurship among youths might stimulate them directly and at the same time it could influence positively the generations they belong to and the communities where they develop their activity.

Achieving the general objectives of the European Union Sustainable Development Strategy or of the member-states, as well as training youths with respect to the necessary competences of the knowledge-society might be achieved also by involving youths in actions for meeting these purposes.

The youths of today are the hope and potential of the future. Youths should be more mobile, multicultural and technologically skilled than before.

Among the advantages of using young labour force in achieving the goals of a sustainable society might be enumerated: 
Bălan M. (2017)

Youth Labour Market in Romania's Development Regions in the Framework of Sustainable Development and of a Knowledge-based Economy

- employment of youths on sustainable jobs ensuring the coherence of economic development and increases the potential of local and domestic markets;

- promoting youths for attractive jobs (new jobs created by the Information Technology and the knowledge theory) leads to increased productivity and perspectives at least for maintaining the competitiveness at the level of economic agents (on the specific market);

- the youths' labour market by its performances supports sustainable economic growth;

- the employment structure, based on a young labour force component at least stable if not on increase and with superior training to the average at the labour market level leads to increases in the sustainable economy;

- structural unemployment among youths if based on an employment deficit in classic, historical jobs represents the most severe issue of the current labour market. If the structural deficit of the young labour force on trades and professions is based on unemployment equivalent to the new professional specialisations generated by the educational process, for creating sustainability in the economic development is required to absorb foreign direct investments based on implementing superior generations of technology, comparable to those existing already at the level of the business environment;

- unemployment among youths is given by an increasingly higher component of wage motivation. The poor remuneration of jobs with future potential slows down the process of economic development eroding the fundamentals of sustainable growth;

- the actual unemployment of young labour force in Romania's regions of development is higher than the recorded one because youths are more flexible and adjust quicker to the 'exigencies' of the working environment, at least with respect to two directions:

a) when they maintain the principle of employment according to the profession gained during the educational process, they will seek by migration/mobility corresponding jobs on other markets (in European Union (EU), extra EU);

b) under the conditions in which the internal mobility factor is excluded for various reasons, the significance of the correlation between professional profile on graduation and the one of the job taken is lost, the employment argument being determined by the corresponding earnings. In both instances, at regional and national level the sustainable growth potential develops in a negative direction because the unattained added value corresponding to the professional training is lost;

- sustainable development does not attract and valorise only the potential of the young labour force, but also the need of experimental updating of the youths,

Studia Universitatis "Vasile Goldis" Arad. Economics Series Vol 27 Issue 4/2017 ISSN: 1584-2339; (online) ISSN: $2285-3065$

Web: publicatii.uvvg.ro/index.php/studiaeconomia.Pages $36-54$ 
Bălan M. (2017)

Youth Labour Market in Romania's Development Regions in the Framework of Sustainable Development and of a Knowledge-based Economy

because in the present society but especially in the future one, the average duration for knowledge depreciation decreases to a higher share than the initial education capacity of adjustment.

\section{Conclusions}

It might be stated that the $\mathrm{Y}$ and $\mathrm{Z}$ generations of the young individuals preparing to enter or already in the labour market are caught in a field of pressures between institutional arrangements, the demand of the public and private sector for labour force and their own expectations regarding attractiveness and quality of the job.

In this field of pressures, on short-term, another particularity for these generations is that their negotiation power decreases, meaning that they will accept lower wages and often under the level of their training and on the other hand, these wages will be linked to the next considerable compromise, respectively taking jobs that do not reflect their training level.

Regarding the rather cyclical phenomenon of young persons' unemployment, it is found that in short periods of recession this might be regarded (from the perspective of the new requirements of structural change of the labour market) as an opportunity for improving and deepening their studies. However, the reverse is that even in periods of resuming economic growth, the young individuals will continue to have low negotiation power, continuing to work for low wages or agreeing to labour contracts for determined periods of time or part-time contracts. Moreover, if options are made for new labour force layoffs, due to new unfavourable economic conjectures, young people will be the first dismissed without the benefit (because of contracts on determined periods of time or parttime contracts or other forms of temporary employment) of the even occasional investments of the employers in the employed labour force under the form of improved vocational training. This will lead to the depreciation of the human capital and to losses of added value that if better valued by improved training investments could have represented one of the most valuable resources of the company on long-term.

In Romania, and implicitly at the regions' level these phenomena are even more acute and the demographic component on permanent decrease of the young cohorts entering into the education and vocational training system is associated with other worrying phenomena, for instance labour migration. In this context, it might be stated that Romania is in full process of 'brain-drain' with respect to young highskilled individuals, entire categories of higher educated youths who achieved levels of excellence (computer science experts, physicians) emigrating for labour abroad immediately after completing their studies. The reasons of the young Romanian individuals are of economic and social nature, the imperfections of the specific 
Bălan M. (2017)

Youth Labour Market in Romania's Development Regions in the Framework of Sustainable Development and of a Knowledge-based Economy

institutional framework, the attitude of employers in negotiating conditions and wages, the lack of perspective in career and in setting up a family representing all true push factors for emigration but also as many reasons for the discouragement and disengagement of the youths regarding the national labour market.

Increasing the insertion degree of the youths in the labour market within the Information society may be achieved by endowing them with the so-called keycompetences (skills, knowledge, know-how and adequate attitudes to each context) and by adopting additional measures that should be efficient on short-term and sustainable on long-term (measures for stimulating employment of young individuals, social protection measures required for youths, measures of improving opportunities for youths on the labour market).

Creating the premises for youths' accountability by generating favourable conditions for them to develop their skills, to work and be actively involved in the development of the society are essential for the sustainable economic and social growth. Nevertheless, youths' insertion in the labour market is a huge challenge for the Government and for the local authorities at the same time. In this context, better attention should be paid to the active labour market policies and measures that would aim at the various groups and sub-groups of youths, including here the NEET youths.

\section{References}

1. Barro J. (2001), Human Capital and Growth, The American Economic Review Vol. 91, No. 2, Papers and Proceedings of the Hundred Thirteenth Annual Meeting of the American Economic Association (May, 2001), http://www.jstor.org, Accessed 10 november 2015;

2. Berlingher V. (2014), Study on the Identification of the Professional Integration Needs - Maramureş County, Studia Universitatis "Vasile Goldiș" Arad - Economics Series, Vol 24, No 4 (2014) http://publicatii.uvvg.ro; Accessed 25 May 2017;

3. Cochran \& Lekies (2008), Skills for success in the knowledge economy, www.youthsuccess.osu.edu, Accessed 5 June 2013;

4. Doiron D. and Gorgens T. (2008), State dependence in youth labour market experiences, and the evaluation of policy interventions, Journal of Econometrics, 145, 8197, https://ideas.repec.org/e/pdo180.html, Accessed 11 December 2014;

5. Enderle K. (2008), Frech, frei, fordernd [Îndrăzneţi, liberi, revendicativi] în Personalmagazin Nr. 12/08, p.12;

6. Eurostat statistics, www.eu.europa.eu, Accessed 12 July 2017;

7. Gregg P. (2001), The impact of youth unemployment on adult unemployment in the NCDS, Economic Journal, Vol. 111, pp. 626-53, http://citeseerx.ist.psu.edu, Accessed 18 Octomber 2013;

8. Gregg P. and Tominey E. (2005), The wage scar from youth unemployment, CMPO Working Paper Series No. 04/097, University of Bristol (forthcoming in Labour Economics), http://www.bristol.ac.uk, Accessed 19 October 2016; 
Bălan M. (2017)

Youth Labour Market in Romania's Development Regions in the Framework of Sustainable Development and of a Knowledge-based Economy

9. Hanushek E.A. \& Kimko D.D. (2000), Schooling, Labor-Force Quality, and the Growth of Nation, Published by: American Economic Association, http://www.jstor.org, Accessed 28 June 2013;

10. Möller and Umkehrer (2014), Are There Long-Term Earnings Scars From Youth Unemployment in Germany?, Discussion Paper No. 14-089 http://ftp.zew.de, Accessed 25 July 2016;

11. Mroz and Savage (2006), The Long-Term Effects of Youth Unemployment, http://www.unc.edu, Accessed 21 January 2015;

12. National Agency for Labour Force Employment, www.anofm.ro, Accessed 2 September 2017;

13. Neagu O. et al. (2016), Human Capital Quality and Development: An Employers' and Employees' Comparative Insight, Studia Universitatis "Vasile Goldiș" Arad - Economics Series, Vol 26, No 3 (2016), http://publicatii.uvvg.ro; Accessed 5 May 2017;

14. OECD and ILO (2014), Report on youth employment and apprenticeships prepared for the G-20 Labor and Employment Ministerial Meeting, Melbourne, Australia, 10-14 September 2014, www.ilo.org, Accessed 6 April 2016;

15. Parment A. (2009): Die Generation Y-Mitarbeiter der Zukunft [nota traducător: Generaţia Y - Angajaţii viitorului], p. 21;

16. Romania's Yearbook 2016, National Institute of Statistics;

17. Schmillen A. \& Umkehrer M. (2013), The Scars of Youth - Effects of Early-Career Unemployment on Future Unemployment Experience, IAB Discussion Paper Articles on labour market issues, 6/2013, www.iab.de, Accessed 8 March 2014;

18. TEMPO-online databank, National Institute of Statistics, www.insse.ro__Accessed 10 September 2017; 